\title{
Albian calcareous nannofossils from the Gault Clay of Munday's Hill (Bedfordshire, England)
}

\author{
JASON A. CRUX \\ BP Exploration Inc, Sage Plaza, 5151 San Felipe, PO Box 4587, Houston TX 77210, USA
}

\begin{abstract}
Abundant and diverse Middle and Upper Albian nannofossil assemblages are present in the Gault Clay * exposed at Munday's Hill, Bedfordshire, England. The section was deposited between the first appearance datums of Tranolithus orionatus and Eiffellithus turriseiffeli. This interval can be further subdivided, using the last appearance of Braloweria boletiformis and the first appearances of Axopodorhabdus albianus, Owenia hilli sp. nov. and Eiffellithus monechiae sp. nov.

The presence of Braloweria boletiformis, Ceratolithina hamata and Gaarderella granulifera, only at this and other north-west European localities, defines a unique endemic nannofloral province. Low latitude species are present throughout the studied section and first and last appearance datums of species are nearly synchronous, both at Munday's Hill and in other areas. This indicates continuous marine connections between Munday's Hill and low latitude areas through the Mid and Late Albian.

Abundance patterns of high latitude nannofossils, primarily Repagulum parvidentatum and Seribiscutum primitivum, suggest that relatively cold waters dominated in the Munday's Hill area near the base of the Middle Albian. The abundance of high latitude taxa gradually decreased towards the end of the Middle Albian, but temporarily increased at the base of the Upper Albian. The abundance of high latitude taxa was relatively low throughout the lower half of the Upper Albian and intermediate to low in the upper half of the Upper Albian.

Two new genera, Braloweria gen. nov. and Owenia gen. nov., and two new species, Owenia hilli sp. nov. and Eiffellithus monechiae sp. nov., are described.
\end{abstract}

\section{INTRODUCTION}

During the Mid and Late Albian, an epicontinental sea covered much of what is now north-west Europe. This sea was connected to the Tethys-Proto-Atlantic seas in the south and to the high northern latitudes via narrow passageways (Fig. 1). North-west Europe was during this time, intermittently influenced by water masses from both the south and the north due to regional transgressions and regressions and tectonic processes. Studies of ammonites (Owen, 1971, 1973) have shown that the north-west European faunas of the Middle and Upper Albian sometimes showed strong provincialism and sometimes varying degrees of influence of Tethyan or high latitude elements. Black (1972, 1973, 1975) described numerous calcareous nannofossil species from the Gault Clay (Middle and Upper Albian) of south-east England which have never been recorded elsewhere. Manivit (1976) suggested that these species formed a distinct nannofloral province restricted to north-west Europe.

This study aims to study the stratigraphic distribution of calcareous nannofossils present in the Gault Clay at Munday's Hill, Bedfordshire, England. Furthermore, to compare the results with nannofossils from other areas and to ammonite and foraminiferal faunas in order to trace palaeoceanographic variations in north-west Europe during the Middle and Upper Albian.

\section{MATERIALS AND METHODS}

A section of Gault Clay exposed in the Munday's Hill pit, near Leighton Buzzard (Grid ref. SP 939279), is chosen for this study (Fig. 1). The Munday's Hill pit contains well preserved and diverse nannofossil assemblages which show great variation through time. During the Mid and Late Albian, the area was connected to open marine seas to the south and north and was influenced by both low and high latitude waters. The section has previously been analysed for ammonite faunas (Owen, 1972) and details of the ammonite stratigraphy, to which the nannofossil samples are correlated, are presented in Fig. 2. For a full description of the Munday's Hill section, see Owen (1972).

Thirty six samples were collected from the Middle Albian Hoplites dentatus ammonite Zone, to the Upper Albian Mortoniceras inflatum ammonite Zone. The very base of the dentatus Zone was not sampled, thus the lowermost Middle Albian is not represented. A stratigraphic break occurs in the middle of the section with part of the Euhoplites loricatus, all of the E. lautus and part of the inflatum ammonite Zones missing. The Stoliczkaia dispar ammonite Zone from the uppermost Albian is also missing. Details of the samples are presented in Appendix 1. Of the 36 samples, the lowermost (sample 11) was barren of nannofossils, but the remaining 35 samples contained abundant and diverse nannofloras. Diversity ranged from 39 to 54 species (Fig. 3). All assemblages showed signs of etching, with some overgrowth of secondary calcite in the higher samples examined. Roth and Krumbach (1986) considered dominance of the nannofossil assemblages by Watznaueria barnesae as a sign of poor preservation. In the samples studied, $W$. barnesae was very abundant only in samples 22, 33 and 34 . Samples 33 and 34 did show low diversities, however, sample 22, contains 50 different species. The nannofossil content of the rock samples increases in the Upper Albian relative to the Middle Albian. Samples 27 - 29 are slightly less well preserved than the other samples.

The samples were prepared for examination in the light microscope using the methods described in Crux (1989). Visual abundance estimates of all species observed were made at X1562 magnification. Detailed abundance counts on selected species were made at X1000 magnification following a method described by Backman and Shackleton (1983). All specimens were counted in 25 fields of view with a diameter of $250 \mu \mathrm{m}$. (A wide field lens was used.) These abundances are presented as number of specimens per square millimeter in the slide. Selected samples were also examined in the scanning electron microscope (SEM) using a centrifuge preparation technique described by Taylor and Hamilton (1982). 


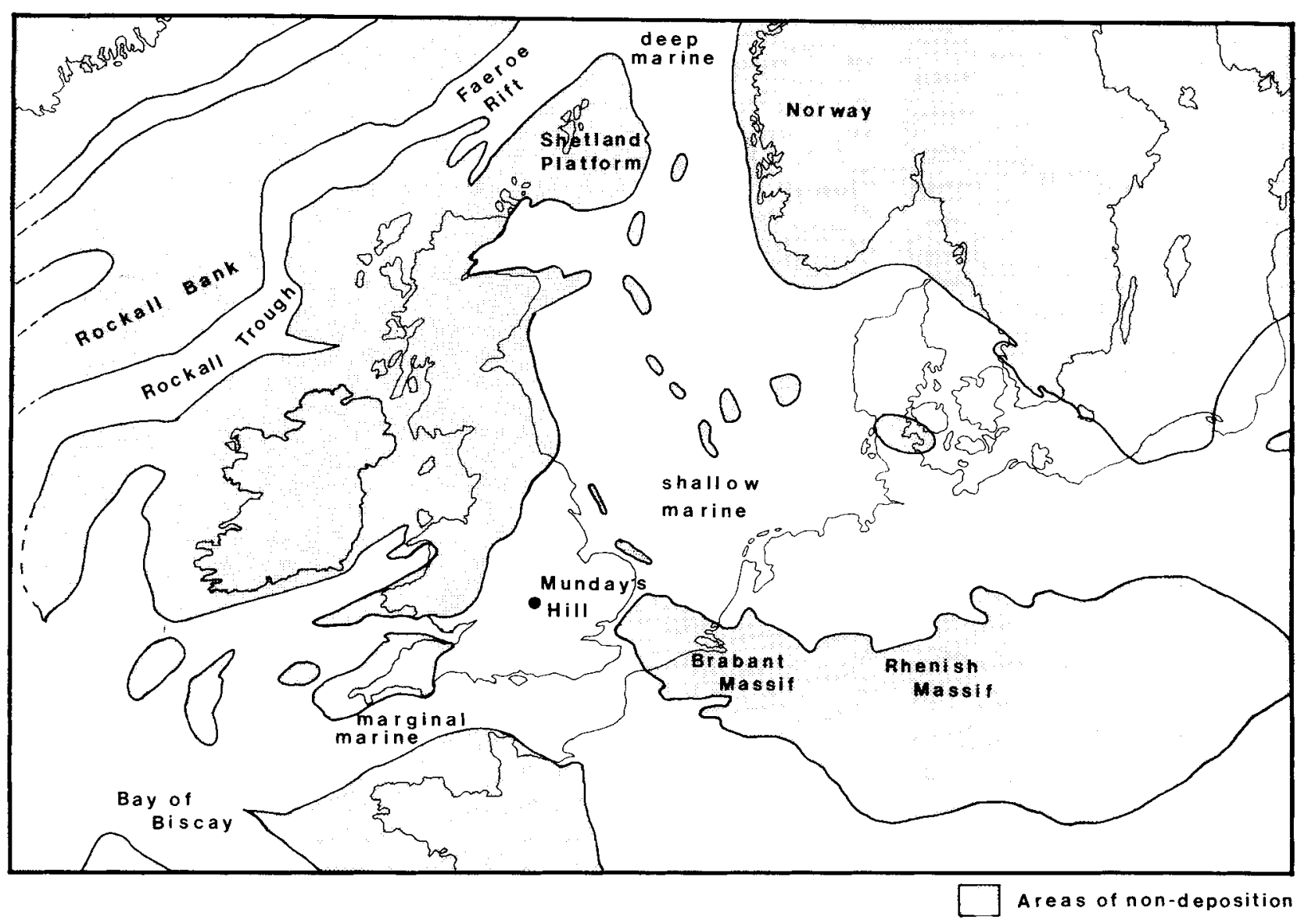

Fig. 1. Palaeogeographic and palaeoceanographic reconstruction of the Albian of north-west Europe. After Ziegler (1982).

\section{NANNOFOSSIL BIOSTRATIGRAPHY}

The whole of the stratigraphic interval exposed in Munday's Hill lies between the first appearance datums of the nannofossils Tranolithus orionatus and Eiffellithus turriseiffeli. This interval equates to the upper part of the Prediscosphaera cretacea Zone of Thierstein (1971), Zone $8 \mathrm{~b}$ of Sissingh (1977) emend Perch-Nielsen (1979) and the Prediscosphaeracretacea to Axopodorhabdus albianus Zones NC 8-9 of Roth (1978). There is potential to further subdivide this time/rock interval using nannofossil datums of both a local and more cosmopolitan scale. In ascending order these are:

\section{Last appearance datum (LAD) of Braloweria boletiformis}

This species has never been recorded outside south-east England. Black (1972) reported it to have a LAD in Bed III (niobe Subzone) at Copt Point, Folkestone, $15 \mathrm{ft}$ above the base of the Gault Clay. He also recorded its occurrence in the basal beds of the Lower Gault in Cambridgeshire, Norfolk and Suffolk. This agrees with the present study where this LAD is recorded in sample 21 , which was collected from near the intermedius/niobe Subzonal boundary.

Braloweria boletiformis is probably endemic to north-west Europe. Its LAD is a useful event in this area but is unlikely to be recorded elsewhere.

\section{LAD of Hayesites albiensis}

Hayesites albiensis has previously been recorded to co-occur with E. turriseiffeli by Roth and Thierstein (1972), Romein (1975),
Thierstein (1976), Manivit et al. (1977), Verbeek (1977), Noël (1980), Amedro et al. (1981), Taylor (1982), Watkins and Bowdler (1984) and Wiegand (1984). Manivit et al. (1977) defined the Hayesites albiensis Subzone as the interval where E. turriseiffelli and $H$. albiensis co-occur. In the present study, $H$. albiensis was found to have its LAD below the first occurrence of Eiffellithus monechiae, the ancestral species of E. turriseiffeli. HayCesites albiensis has a LAD in the niobe Subzone at Munday's Hill, which is earlier than recorded in most other studied sections. Some of the difference in this record may be due to the hiatus which results in the absence of part of the niobe, all of the subdelaure $i$ to daviesi and part of the cristatum Subzones in the Munday's Hill section. Wise (1983) also recorded an early LAD for $H$. albiensis before the FAD of $E$. turriseiffeli in the high latitude South Atlantic DSDP Site 511. It thus appears that $H$. albiensis has a shorter stratigraphic range in high latitudes and is probably unreliable for biostratigraphical purposes in such areas.

\section{FAD of Axopodorhabdus albianus}

The FAD of A. albianus was used by Cepek and Hay (1969) and Roth (1978) as a zonal boundary. Roth (1978) recorded this event to lie between the FAD of T. orionatus and the FAD of E. turriseiffelli. This sequence of events was also recorded by Thierstein (1973, 1976), Manivit (1976), Amedro et al. (1981), Hojjatzadeh (1981), Taylor (1982) and Wise (1983). Perch-Nielsen (1985) questioned the reliability of the FAD of A. albianus as a biostratigraphical datum because of earlier stratigraphic records. Romein (1975), Hill (1976) 


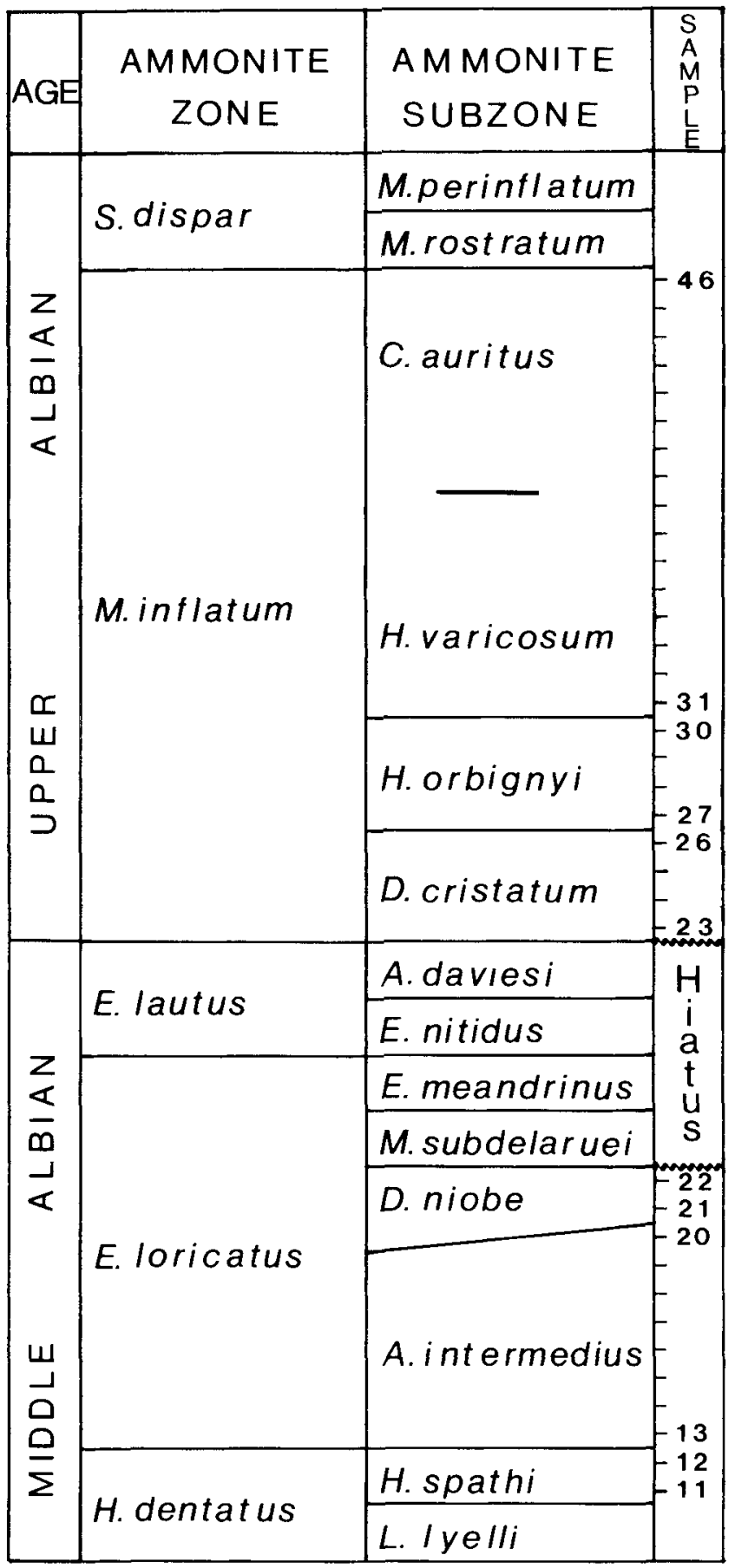

Fig. 2. Sample distribution compared to the ammonite zonal scheme of the north-west European province (Owen, 1984).

and Cepek (1982) all recorded the FAD of A. albianus before the FAD of T. orionatus. Cepek's (1982) samples may have been contaminated as he also records Micula staurophora in the Lower Albian. Hill's (1976) FAD of T. orionatus (exiguus) lies within the Upper Albian and thus this record is probably not its true first occurrence. Romein (1975) only found A. albianus in one sample below $T$. orionatus. In conclusion, it is more likely that the correct order of events is: the FAD of $T$. orionatus followed by the FAD of A. albianus.
The FAD of A. albianus lies within the niobe Subzone at Munday's Hill. This is slightly younger than its FAD recorded by Amedro et al. (1981) from Boulonnais in the intermedius Subzone, but slightly older than Black's (1972) record from Bed V at Copt Point (nitidus Subzone). The FAD of A. albianus thus appears to be a reliable cosmopolitan biostratigraphical datum.

\section{FAD of Owenia hilli}

The only previous record of this species is by Hill (1976) who recorded it in the Upper Albian of Texas under the name Amphizygus brooksii ssp. nanus. His observation of a FAD of this species at the base of the Upper Albian agrees with the findings of the present study, although at Munday's Hill, the base of the Upper Albian is absent due to a break in sedimentation. This species is rare in both Texas and England but its distinctive appearance may make it useful in future biostratigraphical studies.

\section{FAD of Corollithion signum}

Corollithion signum has been recorded in strata as old as the Early Albian (Bukry, 1969) and by several authors in the Middle Albian: Wise and Wind (1977), Perch-Nielsen (1979) and Roth (1983). Many authors don't record this species until the Upper Albian. These inconsistencies in the level of the FAD of $C$. signum are possibly caused by differences in taxonomic concepts. Corollithion signum probably evolved from Corollithion achylosum (PerchNielsen, 1985) through an intermediate form; Corollithion protosignum. The lineage involves the change from the circular $C$. achylosum to the hexagonal $C$. signum. This change is gradual and thus the FAD of $C$. signum is difficult to define precisely.

In the present study, the FAD of $C$. signum is recorded in the cristatum Subzone at Munday's. Hill. The usefulness of this event as a biostratigraphical datum is limited by the inconsistency of identification between different authors and its rare occurrence in most areas.

\section{Last common/abundant occurrence of Repagulum parvidentatum}

This biostratigraphical datum was used by Jakubowski (1987) to define the top of his R. parvidentatum Zone (NLK 5) in the Middle Albian of the Moray Firth (North Sea, offshore UK).

At Munday's Hill, common/abundant $R$. parvidentatum occurs through the Middle Albian and into the base of the Upper Albian (cristatum Subzone). Repagulum parvidentatum is also common in sample 45 from the varicosum-auritus Subzones. It has been observed to be common/abundant when co-occurring with $E$. turriseiffelli on the Mre-Trøndelag Platform offshore Norway (Crux, unpublished). It thus appears that the last common/abundant occurrence of $R$. parvidentatum is unreliable as a biostratigraphical event. It is diachronous and can repeat itself in the same area. A further problem is that Jakubowski (1987) did not define the terms common and abundant.

\section{FAD of Tegulalithus tessellatus}

The FAD of T. tessellatus is recorded in the varicosum-auritus Subzones of Munday's Hill. Other records of this species include Stradner, et al. (1968) from the Albian of Holland, Black (1973) from the Upper Albian of England, Thierstein (1973) from the Upper Aptian (Lithastrinus septentrionalis) and Roth (1983) from the Upper Aptian to Lower Albian of the western North Atlantic ( $L$. 


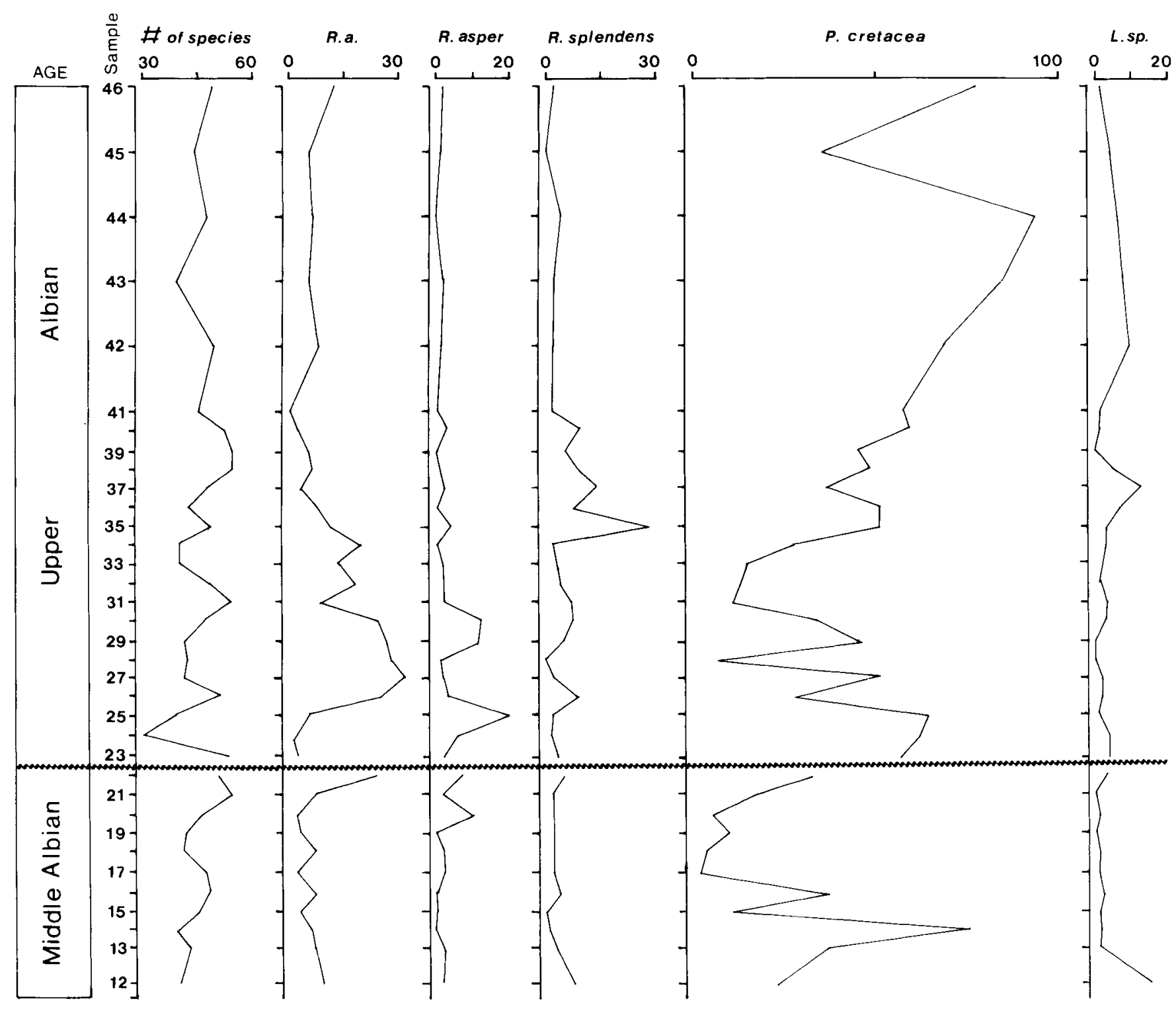

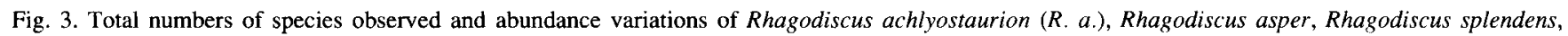
Prediscosphaera cretacea and Lithastrinus sp. (L. sp.) in the studied samples.

septentrionalis). Roth's (1983) record is not illustrated and his range chart shows two occurrences of $L$. septentrionalis. It is probable that the higher record is of $T$. tessellatus, which many authors consider synonymous with $T$. septentrionalis. It appears that $T$. tessellatus has an earlier first occurrence outside north-west Europe than it does in the English Gault. The FAD of this species could be used as a local biostratigraphical event, but it is unreliable over great distances.

\section{FAD of Eiffellithus monechiae}

Opinions on the taxonomic divisions recognised in the early Eiffellithus species differ from author to author. Most authors agree that in the Upper Albian, species of Eiffellithus, with a central cross approximately aligned with the long and short axes of the elliptical coccolith (although often referred to as Vekshinella angusta), occur below the level of the first $E$. turriseiffeli. This sequence of events has been documented by Hill (1976), Verbeek (1977), Perch-Nielsen $(1979,1985)$ and Hill and Bralower (1987).

In the Munday's Hill section, this first Eiffellithus species, $E$. monechiae, occurs in samples 45 and 46 from the varicosumauritus Subzones. This biostratigraphical datum has been recorded from Tunisia, northern Europe and the USA. It therefore appears to be useful for inter-regional correlation

\section{REGIONAL PALAEOGEOGRAPHY AND PALAEOCEANOGRAPHICAL RECORD}

The north-west European Mid and Late Albian epicontinental sea extended from south-east England across the North Sea, Denmark, northern Germany, Poland and into the USSR (Fig. 1). A shallow marine connection existed across north-east France to Tethys. Intermittent shallow marine connections may have existed along the 


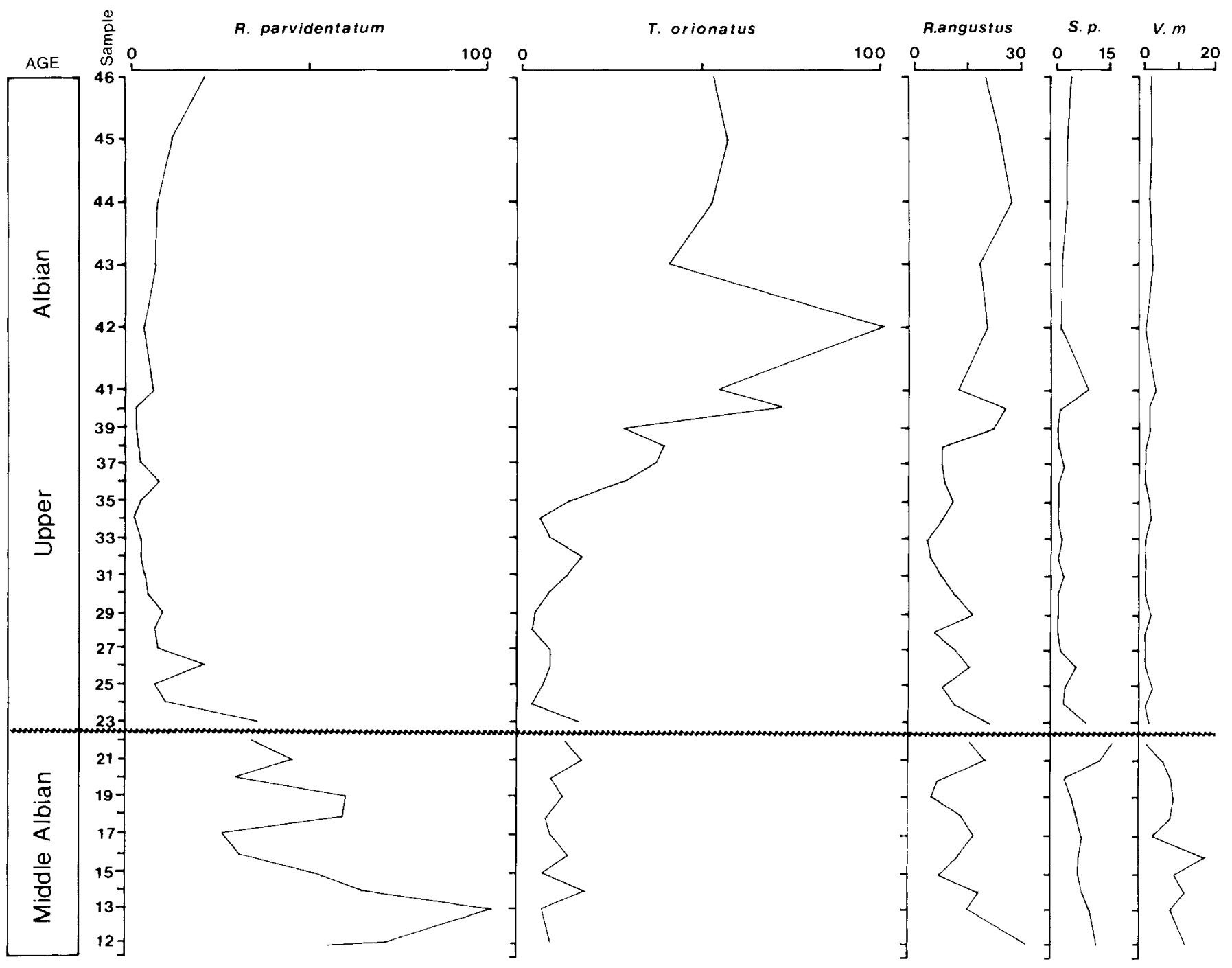

Fig. 4. Abundance variations of Repagulum parvidentatum, Tranolithus orionatus, Rhagodiscus angustus, Seribiscutum primitivum (S. p.) and Staurolithites matalosus $(S . m$.) in the studied samples.

present day English Channel. These are shown on the generalised palaeogeographic maps for the Aptian-Albian and Albian of both Ziegler (1982) and Tyson and Funnell (1987). Owen's (1976) reconstruction of the Middle Albian shows no such connection. A narrow deep marine connection between the Shetland Platform and Norway linked this north-west European sea with Svalbard and east Greenland and possibly the Arctic Ocean. Another deep water connection is shown by Ziegler (1982) linking the proto-Atlantic with the northern North Sea along the Rockall Trough-Faroe Rift.

The extent of the north-west European epicontinental sea varied with the occurrence of regional transgressions and regressions. These also affected the marine connections with other areas. Owen (1976) reported an expansion of the area of marine deposition at the beginning of the Middle Albian. This transgression reached a maximum in the intermedius Subzone when the first Albian nannofossil bearing marine clays were deposited at the Munday's Hill area. At the end of the Middle Albian, a short but widespread period of regression and erosion removed the uppermost Middle Albian sediments from Munday's Hill and much of north-west Europe. This regression has been linked to the onset of sea floor spreading in the Rockall Trough (Roberts et al., 1981). Owen (1976) considered that these tectonic disturbances at the end of the Middle Albian opened an ephemeral connection between the Arctic and the European seas. Tectonic disturbances caused a further transgression in the cristatum Subzone at the beginning of the Late Albian. Marine connections were once again established with the Tethys-Proto-Atlantic area through the Polish Trough and the Paris Basin and presumably the Bay of Biscay and the Rockall Trough (Ziegler, 1982). The two transgressions discussed above can possibly be related to the global $3 \mathrm{rd}$ order cycles UZA- 1.3 to UZA-1.4 and UZA- 1.5 to the base of UZA-2. 1 of coastal 


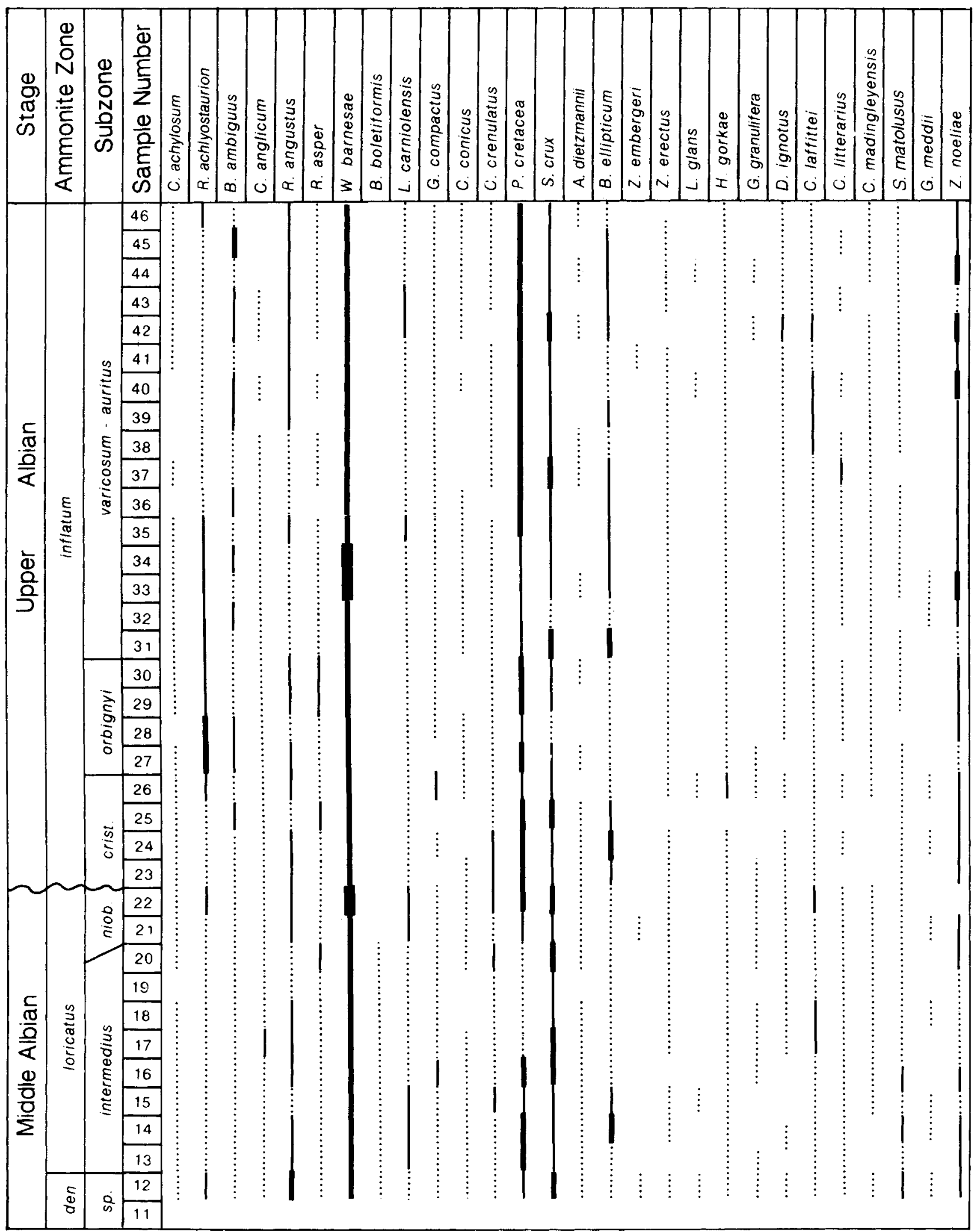

Fig. 5. Stratigraphic distribution of nannofossil species in the Munday's Hill section. Description of abundances in Fig. 7. 


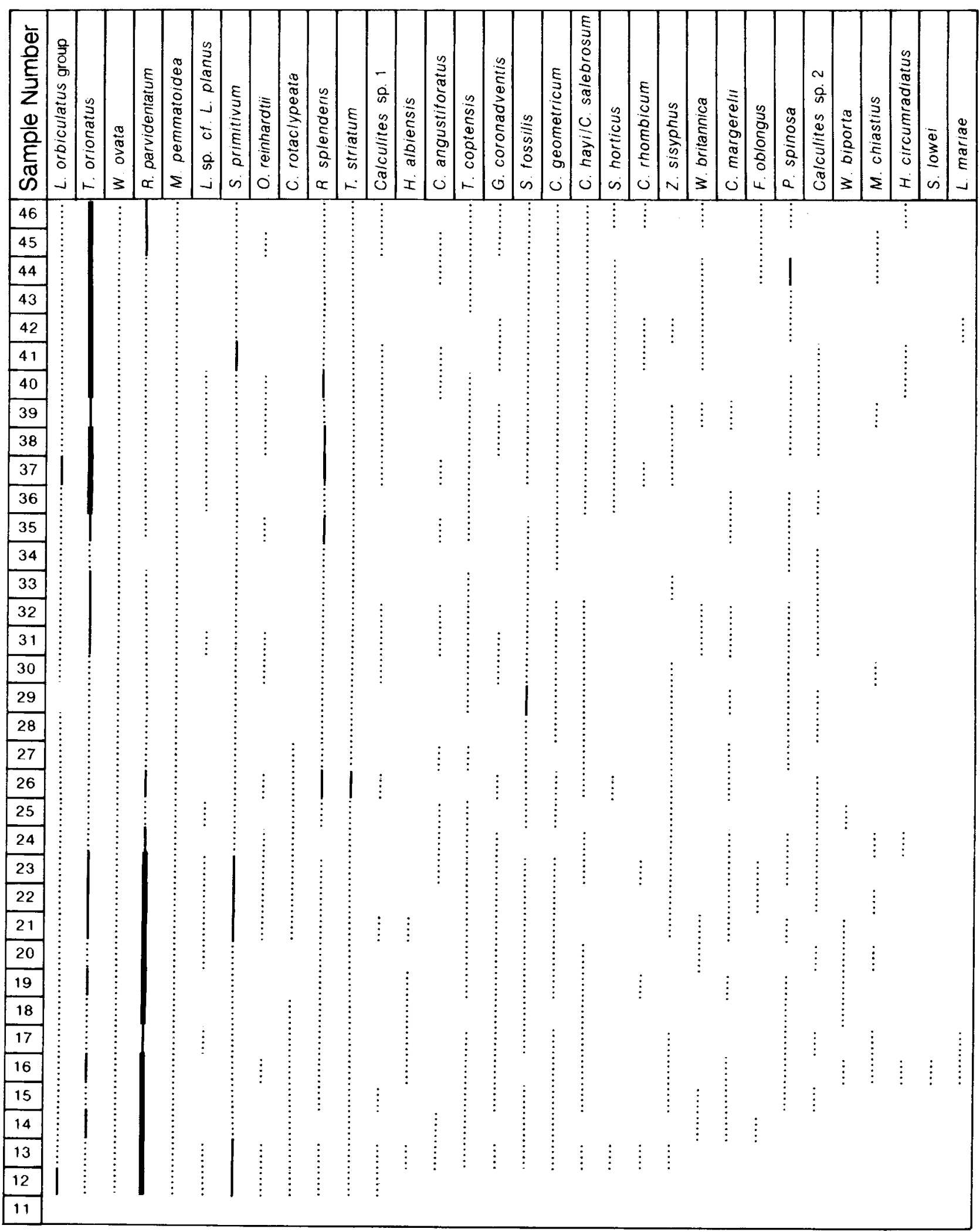

Fig. 6. Stratigraphic distribution of nannofossil species in the Munday's Hill section. Description of abundances in Fig. 7. 


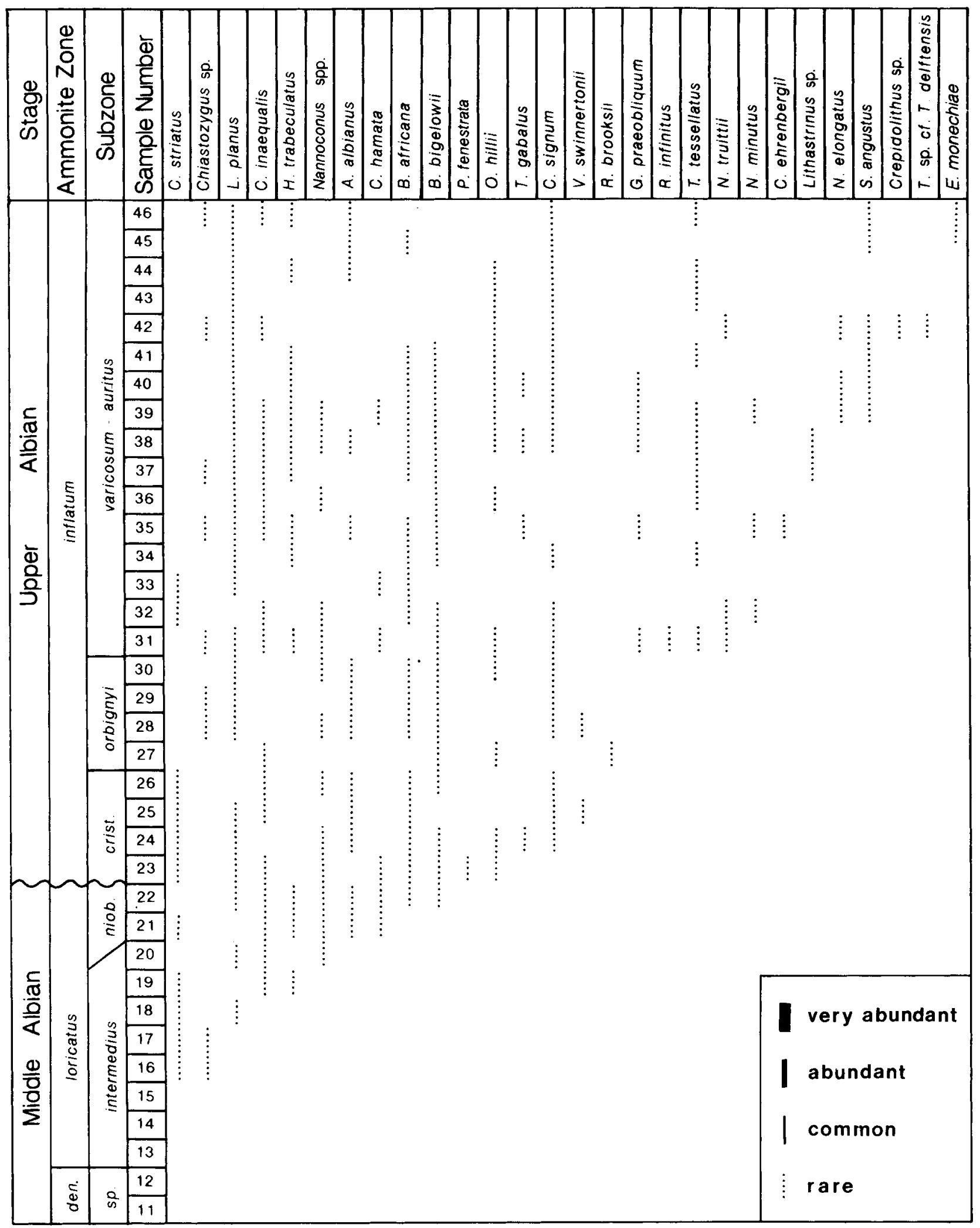

Fig. 7. Stratigraphic distribution of nannofossil species in the Munday's Hill section. Very abundant $>5$ specimens/field of view, Abundant $>1$ specimen/field of view, Common $>1$ specimen/5 fields of view, Rare $<1$ specimen/field of view. 


\section{Results of abundance counts}

Abundance counts were performed on ten taxa in order to evaluate their significance as palaeoenvironmental indicators (Figs. 3 and 4). The species were chosen because it was observed in the initial analysis that they significantly varied in abundance in different parts of the section, and that they were common enough to make abundance counts meaningful.

Rhagodiscus achlyostaurion, $R$. asper and $R$. splendens show a preference for conditions during the topmost niobe Subzone and during the cristatum, orbigny and the lower half of the varicosumauritus Subzones, after a lowpoint in the lowermost cristatum Subzone. Rhagodiscus asper and $R$. splendens were previously sugested to prefer warm surface waters by Roth and Krumbach (1986). As $R$. achlyostaurion shows a similar distribution pattern to these two species, it appears that $R$. achlyostaurion may also prefer warm waters.

Repagulum parvidentatum, S. primitivum and S. matalosus have similar distribution patterns and show distinct preferences for conditions during the spathi to niobe Subzones. Amedro et al. (1981) recorded $S$. primitivum as common in the E. turriseiffeli Zone at Boulonnais, northern France. In the North Sea, Jakubowski (1987) found this species to be abundant up to a level just below the top of the Albian, although his record is based on oil company ditch cuttings samples which give less precise information. Seribiscutum primitivum co-occurs with $E$. turriseiffeli in core samples from the Mre-Trøndelag Platform (offshore Norway) where it comprises up to $5 \%$ of the nannofossil flora (Crux, unpublished) which confirms that $S$. primitivum is a high latitude species. Repagulum parvidentatum is known to prefer high latitudes which thus appear to be the case also for $S$. matalosus. Lithastrinus sp. and $T$. orionatus possibly prefer high latitudes, however, they show a slightly different abundance pattern to $R$. parvidentatum and $S$. primitivum, as they are most common in the upper part of the varicosum auritus Subzones. Tranolithus orionatus, which has been reported as a high latitude species (Roth, 1983) is most abundant at the beginning of the cooling event in the upper Albian. However, $T$. orionatus evolved shortly before the base of the studied section, and its relatively low abundance in the middle Albian may reflect that this species was not yet established. Common for all the high latitude nannofossil species are low abundances in the orbigny through the lower half of the varicosum-auritus Subzones and higher abundances in the Middle Albian, in the cristatum Subzone and in the upper half of the varicosum auritus Subzones. It appears that $R$. angustus has a weak preference for the conditions preferred by high latitude nannofossil species. The abundance pattern of $P$. cretacea is ambiguous to interpret and may indicate nutrient levels.

\section{Low latitude and endemic species}

Nannofossil taxa thought to prefer low latitudes occur in relatively low numbers throughout the Munday's Hill section. Hayesites albiensis appears to have a shorter stratigraphic range than in lower latitudes and $R$. irregularis is absent. Rhagodiscus asper, $R$. splendens, $Z$. erectus, F.oblongus and Nannoconus spp. are less common than they are reported to be in lower latitudes.

Braloweria boletiformis and Ceratolithina hamata have never been observed outside north-west Europe and appear to be endemic to this area. This may also be the case for Gaarderella granulifera, which outside north-west Europe has only been tentatively observed in the Pacific and Atlantic oceans (Roth, 1981, 1983). (See discussion in Taxonomy). Gaarderella granulifera occurs in both the Middle and Upper Albian at Munday's Hill. It has also been recorded from the Middle and Upper Albian at Copt Point and localities in eastern England (Black, 1973). The only reported observations of $B$. boletiformis are restricted to the Middle Albian, where it also occurs at Munday's Hill. A closely related form, Braloweria judithae, was reported by Black (1972) from the Upper Albian of eastern England. Ceratolithina hamata is present in both the Middle and Upper Albian at Munday's Hill. It has previously been recorded from the Middle Albian of Germany (Martini, 1967), Middle Albian Copt Point (Perch-Nielsen, 1988) together with the closely related forms $C$. cruxii and $C$. bicornuta (Middle to Upper Albian) and from the Albian of an oil well onshore The Netherlands (Crux, unpublished).

\section{High latitude nannofossil species}

Nannofossils identified in previous studies to have high latitude preferences occur throughout the Munday's Hill section but their abundance vary at different levels, being most common in the cristatum Subzone and in the upper half of the varicosum-auritus Subzones (Figs. 5 -7). Biscutum dissimilis and S. falklandensis were not observed. These species have only ever been recorded from the high latitudes of the southern hemisphere.

\section{Environmental indicators}

Most of the species identified in previous studies as being more common in epicontinental and continental margin seas, show little variation in their distribution through the Munday's Hill section (Figs. 5-7). The two most common species in this group are $B$. ellipticum and $Z$. noeliae which are slightly more abundant in the Upper Albian than in the Middle Albian. Braarudosphaera spp. and Nannoconus spp. are absent in the lower part of the Middle Albian at Munday's Hill.

No distinctive patterns are observed in the distribution of species previously found to indicate high fertility and unstable environments. Watznaueria barnesae, the only species whose high abundance has been identified as indicating oceanic conditions, is abundant throughout the section, becoming very abundant in two poorly preserved samples ( 33 and 34 ) and also in sample 22.

\section{NANNOFLORAL DEVELOPMENT AND PALAEOCEANOGRAPHICAL IMPLICATIONS}

The earliest stratigraphic records of Crucicribrum anglicum are from the Aptian and Lower to Middle Albian of the relatively shallow water, high latitude, Falkland Plateau and the marginal epicontinental seas of Texas and north-west Europe. It thus appears that this species evolved in shallow, high latitude seas and only occurred in low latitude deep water areas from the Late Albian to Cenomanian. This pattern would agree with other authors observations concerning the closely related genera Broinsonia, Gartnerago and Kamptnerius. These have been recognised to occur more abundantly in shallow shelf seas (Thierstein, 1976; Hartner et al., 1981; Roth and Bowdler, 1981) and to occur earlier in high latitudes (Kamptnerius magnificus (Thierstein, 1976)).

A decrease in abundance of $R$. parvidentatum was noted by Jakubowski (1987) in the Moray Firth and by and Erba et al. (1989) in the Middle Albian of southern England. Wise (1983) shows in his nannofossil distribution chart of DSDP Site 511 from the Falkland Plateau, a reduction in numbers of $R$. parvidentatum at the top of his $T$. orionatus Subzone. At the same level occurs the last $S$. falklandensis. 
The record of the abundance decrease of $R$, parvidentatum by Erba et al. (1989) is stratigraphically earlier than observed in the present study. This would suggest that the abundance decrease of $R$. parvidentatum is diachronous, occurring later at Munday's Hill than in southern England. It is possible that the reduction in abundance of this cold water preferring species, occurred first at lower latitudes and moved diachronously towards higher latitudes in both hemispheres. Unfortunately, neither Wise's (1983) or Jakubowski's (1987) records are precisely dated by ammonites to give us further data on this. However, it is likely that this event indicates reduced influences of cold surface water masses. Erba et al. (1989) favoured a transgressive event displacing the Arctic watermasses of which $R$. parvidentatum was characteristic, to have caused its abundance decrease. In the Munday's Hill section, $R$. parvidentatum returns with increased abundances in the upper half of the varicosum-auritius Subzones, however, it does not become as common as in the Middle Albian. No return of $R$. parvidentatum during the Albian is noted in the southern hemisphere at DSDP Site 511.

Other species previously identified to have high latitude affinities also show some increase towards the top of the Munday's Hill section, in particular, $S$. primitivum, $S$. horticus, $Z$. noeliae and $T$. tessellatus in combination with species suggested in this study to prefer colder waters; Lithastrinus sp., $R$. angustus and $S$. matalosus. In the southern hemisphere, Wise (1983) reported $S$. primitivum to be common through the upper part of his $P$. cretacea Zone, becoming abundant just before the FAD of $E$. turriseiffeli. This abundant occurrence continues through the E. turriseiffeli Zone. A similar pattern was also recorded by Wise and Wind (1977) from the Falkland Plateau and by Thierstein (1974) at DSDP Site 258 in the high latitudes of the Indian Ocean. It thus appears that the advance of colder surface waters in the late inflatum-dispar Zone occured in both the northern and southern hemispheres.

When marine sedimentation commenced at Munday's Hill in the spathi Subzone, the nannofloras were abundant and diverse. Forty species were present in the lowermost sample from the spathi Subzone, rising to 59 species in the niobe Subzone (Fig. 3). High total abundances and diversified nannofossil assemblages persisted throughout the studied section, suggesting that the Munday's Hill area continuously had marine connections with areas outside northwest Europe. The continuous presence, although in relatively low abundances, of species with low latitude affinities, indicates inflow of waters from the Tethys and proto-Atlantic seas. The approximately synchronous FAD's of Axopodorhabdus albianus, Owenia hilli and Eiffellithus monechiae, at Munday's Hill and at more southerly localities, supports this view.

The distribution of low latitude and endemic nannofossil species is similar to their ammonite counterparts. The species identified as being endemic to north-west Europe, could possibly also be present in the high latitude Boreal/Arctic as we know little about the nannofossils of these areas. However, they were not reported from the Moray Firth area (North Sea, offshore UK) by Jakubowski (1987) and have not been observed by the author in oil company wells offshore Norway. Furthermore, they do not have the bipolar distribution patterns of other high latitude nannofossil species. However, further studies outside north-west Europe are needed to definitely prove the existence of an endemic nannoflora, although these species were not reported in recent studies by Bralower (pers. comm.).

The nannofossil abundance patterns in north-west Europe suggest that the relatively colder environment near the beginning of the Middle Albian gradually warmed up towards the regressive event at the end of the Middle Albian. In the Upper Albian, this general trend was temporarily interrupted in the lower cristatum Subzone, where high latitude species increase in abundance. Warmer conditions were established by the orbigny Subzone and persisted through the lower half of the varicosum auritus Subzones. During the upper half of the varicosum - auritus Subzones, intermediate to cold surface waters may have prevailed.

This does not completely agree with Kemper (1987), who studied the distribution of pseudomorphs of glendarites and considered the Middle to Late Albian to be a period of climatic stability. The nannofossil abundance patterns show similarities to results obtained from foraminifera. Michael (1979) analysed the coiling direction of the foraminifera Gavelinella spp. (benthic) and Hedbergella (planktonic) through the Albian. During the Middle Albian 50-60\% were sinistrally coiled, indicating cold water conditions. However, a peak of dextrally coiled forms were found at the base of the Middle Albian. This is probably below the base of the Munday's Hill section. The number of sinistral forms dropped rapidly to $40 \%$ at the Middle to Upper Albian boundary, indicating somewhat warmer conditions. Higher in the Upper Albian, $50 \%$ of the foraminifers were sinistrally coiled, before dropping to $35 \%$ by the end of the Albian. Unfortunately, it is not possible to precisely correlate the foraminifer results to the nannofossils, as Michael (1979) did not relate his study against ammonite zones and subzones. His definitions of the Middle and Upper Albian may be different from those used in this study.

The decline in abundance of high latitude nannofossils observed through the uppermost dentatus to loricatus ammonite Zones, equates with the top of Haq et al.'s (1988) UZA-1.3 and the base of their UZA-1.4 coastal onlap cycles. The advance of high latitude species seen at the base of the cristatum Subzone lies near the base of Haq's et al.'s (1988) UZA-1.5 cycle, whereas the cooling interval observed in the uppermost inflatum Zone and into the dispar Zone corresponds with most of their UZA-2.1 cycle. No simple relationship appears to exist between the variations in high/low latitude nannofossil abundances in the Munday's Hill area and the sea level/transgressiveregressive cycles of Haq et al. (1988).

\section{SYSTEMATICS}

Taxonomic references not included in the reference list can be found in Perch-Nielsen (1985) and in the INA Newsletter.

\section{Class Haptophyaceae Christensen 1962 \\ Order Prymnesiales Papenfuss 1955 \\ Suborder Coccolithineae Kamptner 1928 \\ Family Biscutaceae Reinhardt 1964 \\ Genus Crucibiscutum Jakubowski 1986 \\ Crucibiscutum hayi (Black 1971) Jakubowski 1986}

Crucibiscutum salebrosum (Black 1971) Jakubowski 1986

Remarks. Large and small forms of Crucibiscutum have been divided into $C$. hayi and $C$. salebrosum respectively. Jakubowski (1987) used the extinction of $C$. salebrosum to define a zone within the Barremian of the Moray Firth. However, several authors have recorded this species from younger strata. In addition Crux (1989; Pl. 8.10, figs 29-30) recorded the large forms (C. hayi) from the Hauterivian. It thus appears that both forms range throughout most of the Lower Cretaceous and their division on size alone is of doubtful 
value. The two forms were counted as one taxonomic unit in the present study.

\section{Genus Gaarderella Black 1973}

\section{Gaarderella granulifera Black 1973}

(Pl. 2, figs 20-21)

Remarks. Roth (1981) reported G. cf. G. granulifera from the Mid Pacific Mountains, and illustrated the species with a light micrograph (Roth (1981) Pl. 1, figs 5a, b). The illustrated specimen has a narrow -rim with both the outer and inner parts brightly birefringent. In the specimens of this study, the rim is broader and only the inner part is observed to be bright (Pl. 2, fig. 20). In Roth's specimen, the birefringence pattern of the rim indicates that it is imbricate, however, Black (1973) described G. granulifera as having a non imbricate rim. Roth (1983) also recorded $G$. granulifera from the Aptian of DSDP Site 534 located on the Blake Bahama Basin, but did not illustrate the rare specimen recorded. In conclusion, the presence of $G$. granulifera in both the Atlantic and Pacific oceans are not verified.

Family Calyptrosphaeraceae Boudreaux and Hay 1969 Genus Calculites Prins and Sissingh in Sissingh 1977

Calculites sp. 1

(Pl. 1, fig. 4; Pl. 2, figs 5 and 6)

Description. Small elliptical holococcolith with a central perforation. Remarks. No distal view of this species was seen in the scanning electron microscope (SEM). Its assignment to the genus Calculites is only tentative, it does not appear to fit into any other described genus of holococcolith.

\section{Calculites sp. 2}

\section{(Pl. 2, Fig. 7)}

Description. Small bright holococcolith which was only observed under the light microscope. It appears to have a single large central perforation. It differs from Calculites $\mathrm{sp}$. 1 by possessing a distinctive extinction pattem between $x$-nicols which divides the rim into four unequal segments, two small and two large.

Remarks. Its assignment to Calculites is only tentative, it does not appear to fit into any other described genus of holococcolith.

Type species Owenia hilli $\mathrm{n}$. sp.

Genus Owenia gen.nov.

Derivation of name. After H. G. Owen, ammonite specialist.
Diagnosis. Elliptical holococcolith with a narrow outer rim and broad inner rim. A central perforation is crossed by an arched bridge aligned with the short axis of the elliptical coccolith.

Remarks. Owenia differs from Ottavianus Risatti 1973 by lacking its 10-15 irregular rim elements. It differs from the genus Ramsaya Risatti 1973, whose outer rim is wider than the inner rim.

Owenia hilli sp. nov.

(Pl. 1, figs 3 and 6; Pl. 2, figs 1-4 and 8)

1976 Amphizygus brooksii ssp. nanus Bukry; Hill: 122, Pl. 1, figs 1224.

Derivation of name. After M. E. Hill III, nannofossil specialist. Diagnosis. As from the genus Owenia.

Holotype. Pl. 1, fig. 6.

Type locality and horizon. Munday's Hill near Leighton Buzzard, Bedfordshire, England. Grid ref. SP 939279. Upper Gault, cristatum Subzone, sample 23.

Dimensions. Length 2.9-3.5 $\mu \mathrm{m}$; width $2.0-2.1 \mu \mathrm{m}$, two specimens measured.

Remarks. The diagnosis of this species is similar to that of $O$ rastrum partium Varol in Al Rifaiy et al. (1990). The two species differ in the construction of their bridges, $O$. partium is reported and illustrated as appearing to have a cross formed of four elements in X-nicol light. The bridge of $O$. hill $i$ is composed of numerous crystals, which do not appear as a cross in X-nicol light.

Family Ceratolithaceae Norris 1965

Genus Ceratolithina Martini 1967

Ceratolithina hamata

(Pl. 1, fig. 5; Pl. 2, fig. 22)

Remarks. Ceratolithina cruxii Perch-Nielsen 1988 is included in the abundance estimates of $C$. hamata in Fig. 7.

Family Crepidolithaceae Black 1971

Genus Braloweria gen. nov.

Type species Parhabdolithus boletiformis Black 1972

Derivation of name. After T. J. Bralower, nannofossil specialist.

Diagnosis. Elliptical heterococcolith with a loxolith rim structure, the central areas is completely filled with a large single hollow spine composed of numerous laths of calcite. This spine may flare or taper distally.

Remarks. This genus differs from Parhabdolithus Deflandre 1952 in its rim structure. In Braloweria, the rim is of a loxolith structure

Electron micrographs, bars in top left corner $=1 \mu \mathrm{m}$

Explanation of Plate 1

Fig. 1. Tegulalithus tessellatus, plan view, sample 39

Fig. 2. Seribiscutum primitivum, proximal view, sample 17.

Fig. 3. Owenia hilli $\mathrm{n}$. sp., distal view, sample 39.

Fig. 4. Calculites sp. 1, proximal view, sample 39.

Fig. 5. Ceratolithina hamata, sample 23.

Fig. 6. Owenia hilli n. sp., distal view, sample 23.

Fig. 7. Crucicribrum anglicum, proximal view, sample 12.

Fig. 8. Braloweria boletiformis, side view, sample 17.

Fig. 9. Braloweria boletiformis, distal view, sample 17.

Fig. 10. Braloweria boletiformis, side view, sample 17

Fig. 11. Braloweria boletiformis, distal view, sample 17.

Fig. 12. Repagulum parvidentatum, distal view, sample 21 . 

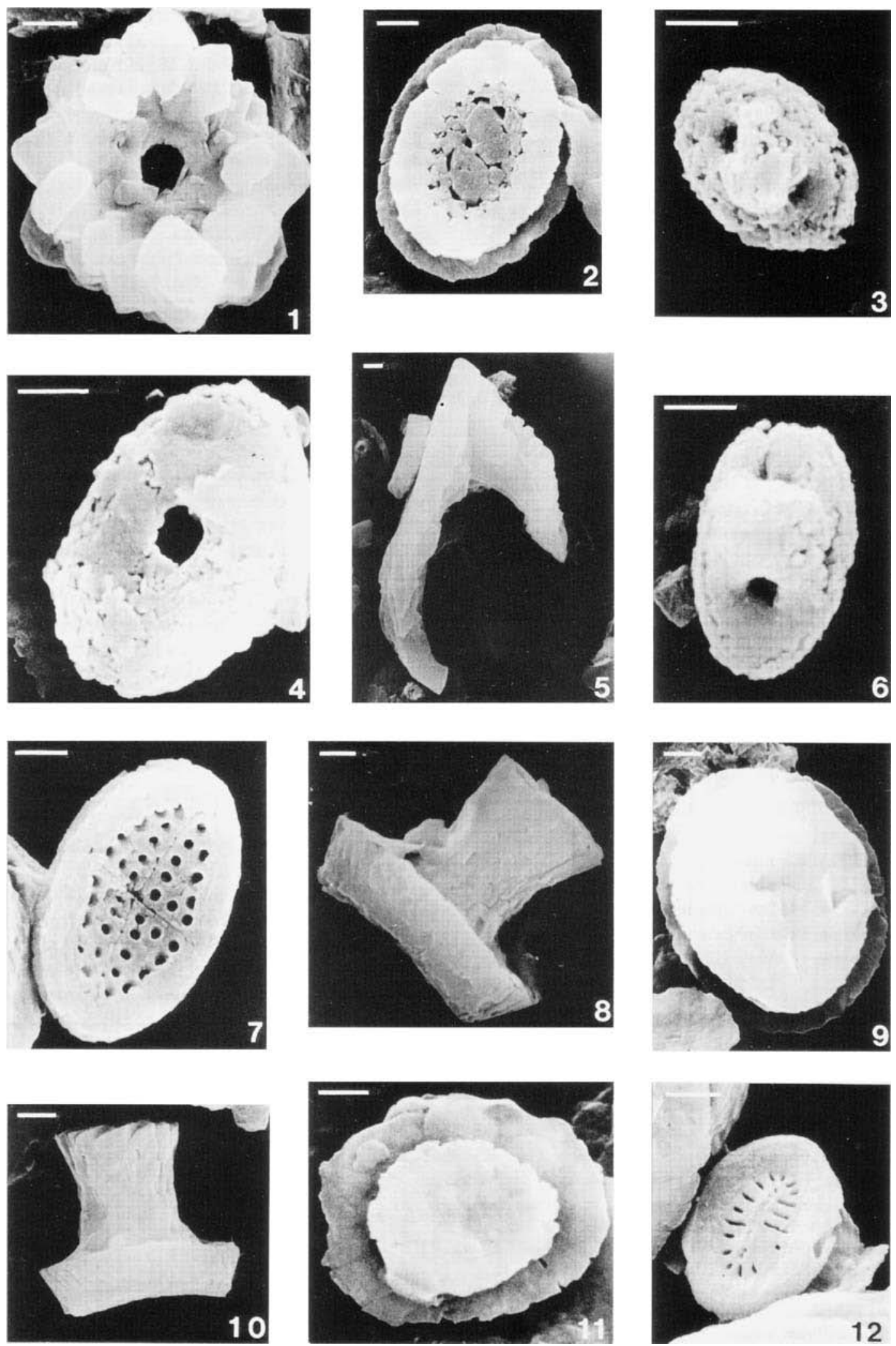
while in Parhabdolithus, the rim is of a protolith structure sensu Bown (1987). Braloweria differs from Rhagodiscus Reinhardt 1967 by the regular construction of its central area which is completely filled by the spine.

Braloweria boletiformis (Black 1972) n. comb.

(Pl. 1, figs 8-11; P1. 2, figs 13-18)

1972 Parhabdolithus boletiformis Black: 29-30, Pl. 3, figs 3, 4, P1. 4, figs 1-3.

Remarks. Black (1972) considered the spines of B. boletiformis to be solid. In the present study, light microscope examinations suggest that they may be hollow (Pl. 2, figs 15-18).

Braloweria judithae (Black 1972) n. comb. 1972 Parhabdolithus judithae Black: 30-31, Pl. 3, figs 5, 6, Pl. 4, fig. 4.

Remarks. This species was not observed in the present study.

Genus Crepidolithus Noël 1965

Crepidolithus sp.

Remarks. This species, which was only seen under the light microscope in one sample, is similar to the Jurassic species Crepidolithus crassus (Deflandre in Deflandre and Fert 1954) Noel 1965. No other evidence for reworking of Jurassic nannofossils was seen, so it is assumed this species is in-situ and as yet undescribed.

\section{Family Eiffellithaceae Reinhardt 1964 Genus Chiastozygus Gartner 1968}

Chiastozygus sp.

Description. Small species of Chiastozygus with a thin central cross. Remarks. This species was not seen in the SEM.

\section{Genus Eiffellithus Reinhardt 1965}

Eiffellithus monechiae sp. nov. Not illustrated

non 1979 Eiffellithus sp. 1 Perch-Nielsen: 243

non 1979 Eiffellithus sp. 3 Perch-Nielsen: 243

1976 Eiffellithus eximius (Stover); Hill: 139, Pl. 6, figs 24-39 (non 19-23, 30-33)
1985 Eiffellithus sp. 1 Perch-Nielsen fig. 35.5 and 35.6 (non fig. 34) 1985 Eiffellithus sp. 3 Perch-Nielsen figs 35.7 and 35.8 (non fig. 34) 1987 Eiffellithus eximius (Stover): Hill and Bralower; 92-93, Pl.1, figs 4-6, Pl. 2, figs 1-4 (non Pl. 1, figs 2, 3, 7 and 8).

Derivation of name. After S. Monechi, nannofossil specialist Diagnosis. A species of Eiffellithus whose central cross is aligned within 20 of the major axes of the elliptical coccolith. The blocky plates of the central area are equal or greater in width than the rim, but do not totally fill the centre.

Holotype. Hill and Bralower, 1987, Pl. 2, fig. 3.

Type locality and horizon. Locality 6264 Hill (1976). North bank of Red River just E. of bridge of US highway 75 just below Texhoma Dam Oklahoma. Duck Creek Formation, Upper Albian.

Dimensions. Length $4.7-6 \mu \mathrm{m}$, width $3.4-4.6 \mu \mathrm{m}, 3$ specimens measured.

Remarks. Eiffellithus monechiae is differentiated from E. eximius by its stratigraphic range, Upper Albian to lowest Cenomanian, rather than the Turonian to Maastrichtian of E. eximius. It is also differentiated by a narrower cycle of blocky elements in the central area although this may vary considerably due to preservation.

Hill and Bralower (1987) grouped E. monechiae with E. eximius on the basis that they found $E$. eximius in the basal Turonian sediments and that they considered it probable that it was present throughout the Cenomanian in very low numbers and as yet undetected by them and other authors. I believe that $E$. monechiae evolved from $S$. angustus in the Late Albian and in turn E. turriseiffeli evolved from it. In the Turonian, E. eximius evolved from E. turriseiffeli. Thus the two forms, although morphologically similar, are different species. This is also a pragmatic approach as the first occurrences of both species are useful as biostratigraphical datums. Staurolithites angustus is differentiated from $E$. monechiae as the blocky elements in the central area are narrower than the outer rim. This definition may be difficult to apply in poorly preserved material where the elements are overgrown, but has worked in sections I have examined from northwest Europe.

\section{Genus Staurolithites Caratini 1963}

Staurolithites angustus (Stover 1966) n. comb.

1966Zygolithus angustus Stover: 147, Pl. 3, figs 14, 15, Pl. 8, fig. 22. 1977 Vekshinella angusta (Stover) Verbeek: 96, P1. 6, figs 11, 12.

Remarks. Staurolithites is the senior synonym of the genus Vekshinella Loeblich and Tappan 1963 although, many authors

Figs 1,2 . Owenia hilli $\mathrm{n}$. sp., $\mathrm{x}$-nicols and bright field, sample 41 .

Figs 3,4 . Owenia hilli $\mathrm{n}$. sp., $\mathrm{x}$-nicols and bright field, sample 23.

Figs 5, 6. Calculites sp. 1, x-nicols and bright field, sample 12.

Fig. 7. Calculites sp. 2, x-nicols, sample 23.

Figs 9,10 . Lithastrinus sp., $\mathrm{x}$-nicols and bright field, sample 37 .

Fig. 11. Repagulum parvidentatum, $\mathrm{x}$-nicols, sample 12.

Fig. 12. Seribiscutum primitivum, $\mathrm{x}$-nicols, sample 23.

Figs 13,14. Braloweria boletiformis, x-nicols and bright field, sample 13.

Figs 15,16. Braloweria boletiformis, x-nicols and bright field, sample 12.

Fig. 17. Braloweria boletiformis, $\mathrm{x}$-nicols, sample 14.

Fig. 18. Braloweria boletiformis, $\mathrm{x}$-nicols, sample 19.

Fig. 19. Crucicribrum anglicum, $\mathrm{x}$-nicols, sample 31.

Figs 20,21. Gaarderella granulifera, x-nicols and bright field, sample 12.

Fig. 22. Ceratolithina hamata, $\mathbf{x}$-nicols, sample 23. 

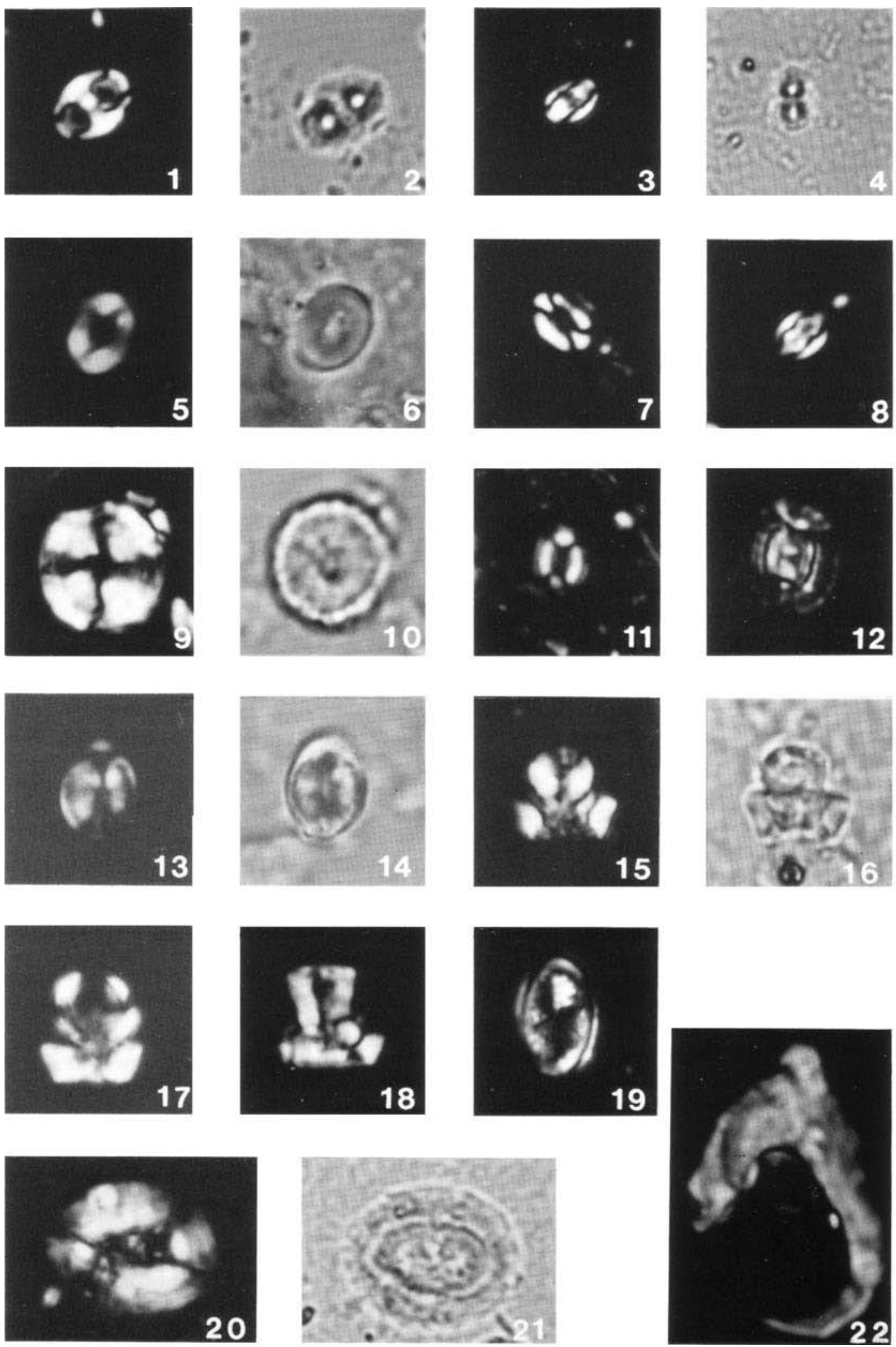
(Bukry 1969) believe it is too poorly illustrated and defined to be useful and have used Vagalapilla Bukry (1969).

Family Polycyclolithaceae Forchheimer 1972

Genus Lithastrinus Stradner 1962

Lithastrinus orbiculatus (Forchheimer 1972) Crux in Crux et al. 1982

Remarks. L. orbiculatus is grouped with L. floralis in the light microscope abundance estimates presented in Fig. 6.

\section{Lithastrinus sp.}

(Pl. 2, figs 9-10)

Description. Large species of Lithastrinus, with 10 or more elements. It appears to be similar to L. planus but has more elements.

\section{Genus Tegulalithus Crux 1986 \\ Tegulalithus tessellatus (Stradner in Stradner et al., 1968) \\ Crux 1986 \\ (Pl. 1, fig. 1)}

Remarks. $T$. tesellatus is differentiated from $T$. septentrionalis by having a much larger central perforation. The large wall forming elements seen in $T$. septentrionalis have not yet been observed in $T$. tessellatus.

\section{Family Prediscosphaeraceae Rood, Hay and Barnard 1971} Genus Prediscosphaera Vekshina 1959

Prediscosphaera cretacea (Arkhangelsky 1912) Gartner 1968

Remarks. Prediscosphaera cretacea as used in this study also probably includes Prediscosphaera columnata (Stover 1966) PerchNielsen 1984 . The two species can only be differentiated when their spines are preserved, which is infrequently, thus a more practical approach is to group them as one species.

\section{CONCLUSIONS}

The last occurrence of Braloweria boletiformis is a reliable biostratigraphic datum within south-east England. The first occurrences of Axopodorhabdus albianus, Owenia hilli and Eiffellithus monechiae appear to be reliable world-wide biostratigraphical datums. The last occurrence of common/abundant Repagulum parvidentatum is diachronous, occurring earlier in low latitudes. The last occurrence of Hayesites albiensis is also diachronous, occurring earlier in high latitudes. The first occurrence of Corollithion signum is an unreliable biostratigraphic event. This species evolves gradually from Corollithion achylosum and thus, its FAD is difficult to define consistently.

A nannofossil floral province, unique to north-west Europe, existed through both the Middle and Upper Albian. Three species, $B$. boletifomis, Ceratolithina hamata (and the closely related C. bicornuta and $C$. cruxii), and Gaarderella granulifera, appear to be endemic to north-west Europe.

The occurrence of low latitude nannofossil species throughout the Munday's Hill section, and the nearly synchronous first and last occurrences of species both at Munday's Hill and in other areas, indicates marine connections with the Tethys-Proto-Atlantic areas throughout the Middle and Upper Albian interval studied.

Decreasing abundances of high latitude nannofossil species, primarily R. parvidentatum and $S$. primitivum, through the Middle Albian suggest that a relatively cold environment near the base of the
Middle Albian gradually warmed up towards the regressive event at the end of the Middle Albian. This general trend was temporarily interrupted at the base of the Upper Albian (lower cristatum Subzone), when high latitude species increased in abundance. Low abundances of high latitude nannofossil species suggest that relatively warm surface water conditions were established by the orbigny Subzone and persisted through the lower half of the varicosum-auritus Subzones. These trends are supported by conclusions based on ammonite and foraminiferal data in previous studies.

This study suggests that Rhagodiscus achlyostaurion increases in abundance in warmer waters and that Rhagodiscus angustus shows a weak preference for colder conditions. Also, Staurolithites matalosus is a cold water preferring species.

\section{ACKNOWLEDGEMENTS}

I thank the British Petroleum plc. for permission to publish this paper and G.L. Eaton, J.E. Williams and M.G. Collett for help in collecting the samples. I thank T. J. Bralower for reading the manuscript.

Manuscript received August 1990

Manuscript accepted August 1991

\section{REFERENCES}

Al-Rifaiy, I., Varol, O. and Lemone, D. 1990. Middle to Late Albian biostratigraphy of the Cuchillo Formation from Sierra de Sapello Mexico. Newsl. Stratigr., 21, 187-200.

Amédro, F., Damotte, R., Magneiz-Jannin, F. \& Manivit, H. 1981. Échelles biostratigraphiques dans l'Albien du Boulonnais (Macro-MicroNannofossiles). Bull. Inf. Geol. Bass., Paris, 18, 3-19.

Applegate, J. L. \& Bergen, J. A. 1988. Cretaceous calcareous nannofossil biostratigraphy of sediments recovered from the Galicia Margin, ODP Leg 103. In Boillot, G., Winterer, E. L. et al., Proc. ODP Sci. Results, Washington (U.S. Govt. Printing Office), 103, 293-348.

Applegate, J. L., Bergen, J. A., Covington, J. M., \& Wise, S. W. 1989. Lower Cretaceous calcareous nannofossils from continental margin drill sites off North Carolina (DSDP Leg 93) and Portugal (ODP Leg 103): a comparison. In Crux, J. A. \& Heck, S. E, van (Eds.), Nannofossils and their Applications, 212-222. Ellis Horwood Ltd., Chichester for British Micropalaeontological Society.

Backman, J. \& Shackleton, N. J. 1983. Quantitative biochronology of Pliocene and Early Pleistocene calcareous nannofossils from the Atlantic, Indian and Pacific oceans. Mar. Micropaleontol., 8, 141-170.

Black, M. 1972. British Lower Cretaceous coccoliths. I. Gault Clay. Palaeontogr. Soc. [Mongr.], 1, 1-48.

Black, M. 1973. British Lower Cretaceous coccoliths. I. Gault Clay. Palaeontogr. Soc. [Mongr.], 2, 49-112.

Black, M. 1975. British Lower Cretaceous coccoliths. I. Gault Clay.Palaeontogr. Soc. [Mongr.], 3, 113-142.

Bown, P. R. 1987. The structural development of early Mesozoic coccoliths and its evolutionary and taxonomic significance. Abh. Geol B. -A., Wien, 39, 33-49.

Bukry, D. 1969. Upper Cretaceous coccoliths from Texas and Europe. Univ. Kansas paleontol. contrib., Article 51, 79 pp.

Cepek. P. 1982. Das Phytoplankton des spaten Apt und fruhen Alb in Nordwestdeutschland. Das kalzitische Nannoplankton des spaten Apt und fruhen Alb (Parhabdolithus angustus-Zone) des Gebietes von Hannover. Geol. Jb., A65, 283-306.

Cepek, P. \& Hay, W. W, 1969. Calcareous nannoplankton and biostratigraphic subdivision of the Upper Cretaceous. Trans. Gulf Coast Assoc. geol. Soc., 19, 323-336.

Crux, J. A. 1989. Biostratigraphy and palaeogeographical applications of Lower Cretaceous nannofossils from north-western Europe. In Crux, J. A. \& Heck, S. E. van (Eds.), Nannofossils and their Applications, 143211. Ellis Horwood Ltd., Chichester, for British Micropalaeontological 
Society.

Erba, E. 1987. Mid Cretaceous cyclic pelagic facies from the UmbrianMarchean Basin: what do calcareous nannofossils suggest? INA Newsl., 9, 52-53.

Erba, E., Guasti, G. \& Castradori, D. 1989. Calcareous nannofossils record fertility and temperature cycles: evidence from the Albian Gault Clay Formation. INA Newsl., 11, 57-58.

Haq, B. U., Hardenbol, J. \& Vail, P. R. 1988. Mesozoic and Cenozoic chronostratigraphy and cycles of sea level change. In Sea-Level Changes - An Integrated Approach, SEPM spec. publ., 42, 71-108.

Hartner, J. G., Wind, F. H. \& Wise, S. W. 1980. The Santonian-Campanian boundary: comparison of nearshore-offshore calcareous nannofossil assemblages. Cah. Micropaleontol., 1980, 9-26.

Hill, M. E. 1976. Lower Cretaceous calcareous nannofossils from Texas and Oklahoma. Palaeontographica B, 156, 103-179.

Hill, M. E. \& Bralower, T. 1987. Early Evolution, Stratigraphy and Taxonomy of Eiffellithus eximius and Closely-Related Species. Abh. Geol. B.-A. Wien, 39, 89-97.

Hojjatzadeh, M. 1981. Mid-Cretaceous (Albian-Cenomanian) calcareous nannofossils from Pont du Fahs (northern Tunisia). Geol. Mag., 118, 161-174.

Jakubowski, M. 1987. A proposed Lower Cretaceous calcareous nannofossil zonation scheme for the Moray Firth area of the North Sea. Abh. Geol.B. A., Wien, 39, 99-119.

Kemper, E. 1987. Das Klima der Kreide-Zeit. Geol. Jb., A96, 5-186.

Kemper, E., Mutterlose, J. \& Wiedenroth, K. 1987. Die Grenze Unter/Ober Hauterive in Nordwestdeutschland, Beispiel eines stratigraphisch zu nutzenden Klima-Umschwungs. Geol.Jb., A96, 209-218.

Manivit, H. 1976. Le Nannoplankton du stratotype de l'Albien. Biozonation systematique, nannofacies, paleoecologie. In Les Stratotypes Francais, Vol. 5, L'Albien de L'Aube. Editions C.N.R.S., 306-346.

Manivit, H., Perch-Nielsen, K., Prins, B. \& Verbeek, J. W. 1977. Mid Cretaceous calcareous nannofossil biostratigraphy. Proc. Kon. Ned. Akad. wetensch. ser. B, 80, 169-181.

Martini, E. 1967. Ceratolithina hamata n, g., n. sp., aus dem Alb von NDeutschland (Nannoplankton, incertae sedis). N. Jb. Geol. Palaont. Abh., 128, 294-298.

Michael, E. 1979. Mediterrane Fauneneinflusse in dem borealen UnterkreideBecken Europas, besonders Nordwestdeutschlands. In Wiedemann, J. (Ed.), Aspekte der Kreide Europas, IUGS Series A, 6, 305-321.

Mutterlose, J. 1988. Das kalkige nannoplankton des NW-Deutschen Valangin und seine paläozeanographische deutung. Berliner geowiss. Abh., A94, 175-209.

Mutterlose, J. 1989. Temperature-controlled migration of calcareous nannofloras in the north-west European Aptian. In Crux, J. A. \& Heck, S. E. van (Eds.), Nannofossils and their Applications, 122-142. Ellis Horwood, Ltd., Chichester for British Micropalaeontological Society.

Noël, D. 1980. Niveaux d'apparition et de disparition relatifs de nannofossiles calcaires utilisables comme reperes stratigraphiques dans le Crétacé Inferieur et Moyen. Cah. Micropaleontol., 1980, 57-83.

Owen, H. G. 1971. Middle Albian stratigraphy in the Anglo-Paris Basin. Bull Br. Mus. nat. Hist. (Geol.) sup. 8, 164 pp.

Owen, H. G. 1973. Ammonite faunal provinces in the Middle and Upper Albian and their palaeogeographical significance. In Casey, R. \& Rawson, P. F. (Eds.), The Boreal Lower Cretaceous. Geol.J. spec. issue $5,145-154$.

Owen, H. G., 1975. The Stratigraphy of the Gault and Upper Greensand of the Weald. Proc. Geol. Ass., 86, 475-498.

Owen, H. G. 1984. The Albian Stage: European Province Chronology and Ammonite Zonation. Cret. Res., 5, 329-344.

Perch-Nielsen, K. 1979. Calcareous nannofossils from the Cretaceous between the North Sea and the Mediterranean. In Wiedemann, J. (Ed.), Aspekte der Kreide Europas. IUGS Series A, 6, 223-272.

Perch-Nielsen, K. 1985. Mesozoic calcareous nannofossils. In Bolli, H. M., Saunders, J. B. \& Perch-Nielsen, K. (Eds.), Plankton Stratigraphy,329426, Cambridge University Press.

Perch-Nielsen, K. 1988. New Lower Cretaceous calcareous nannofossil species from England. INA Newsl., 10, 30-37.

Roberts, D. G. 1975. Tectonic and stratigraphic evolution of the Rockall Plateau and Trough. In Woodland, A. W. (Ed.), Petroleum and the continental shelf of NW Europe, Vol. 1, Geology, 72-89, Applied Science Publishers.

Romein, A. J. T. 1975. Lower Cretaceous calcareous nannoplankton from the Calderon and Parra Formations (SE Spain). GUA Pap. Geol., Ser. 1, 77 88.

Roth, P. H. 1978. Cretaceous nannoplankton biostratigraphy and oceanography of the Northwestern Atlantic Ocean. In Benson, W. E., Sheridan, R. E. et al. Init. Repts. DSDP, Washington (U.S. Govt. Printing Office), 44, 731-759.

Roth, P. H. 1981. Mid Cretaceous calcareous nannoplankton from the Central Pacific: Implications for paleoceanography. In Thiede, J., Vallier, T. L. et al., Init. Repts. DSDP, Washington (U.S. Govt. Printing Office), 62,471-489.

Roth, P. H. 1983. Jurassic and Lower Cretaceous calcareous nannofossils in the western North Atlantic (Site 534): biostratigraphy, preservation, and some observations on biogeography and paleoceanography. In Sheridan, R. E., Gradstein, F. M. et al., Init.Repts. DSDP, Washington(U.S.Govt. Printing Office), 76, 587-621.

Roth, P. H. \& Bowdler, J.L. 1981. Middle Cretaceous calcareous nannoplankton biogeography and oceanography of the Atlantic Ocean. SEPM spec. publ., 32, 517-546.

Roth, P. H. \& Krumbach, K. R. 1986. Middle Cretaceous calcareous nannofossil biogeography and preservation in the Atlantic and Indian Oceans: implications for paleoceanography. Mar. Micropaleontol., 10,235-266.

Roth, P. H. \& Thierstein, H. R. 1972. Calcareous nannoplankton: Leg 14 of the Deepp Sea Drilling Project. In Hayes, D. E., Pimm, A. C. et al. Init. Repts. DSDP, Washington (U.S. Govt. Printing Office), 14, 421-485.

Sissingh, W. W. 1977. Biostratigraphy of Cretaceous calcareous nannoplankton. Geol. Mijnbouw., 56, 37-65.

Stover, L. E. 1966. Cretaceous coccoliths and associated nannofossils from France and the Netherlands. Micropaleontol., 12, 133-167.

Stradner, H. 1963. New contributions to Mesozoic stratigraphy by means of nannofossils. Sixth World Petrol. Congr., Frankfurt 1963, sect. 1 (4), 167-182

Stradner, H., Adamiker, D. \& Maresch, O. 1968. Electron microscope studies on Albian calcareous nannoplankton from the Delft 2 and Leidschendam 1 Deep Wells, Holland. Verh. Kon. Ned. Akad. Wetensch. Afd. Natuurk., 24,1-107.

Taylor, R. J. 1982. Lower Cretaceous (Ryazanian to Albian) calcareous nannofossils. In Lord, A. R. (Ed.), A Stratigraphical Index of Calcareous Nannofossils, 40-80. Ellis Horwood, Chichester for British Micropalaeontology Society.

Thierstein, H. R. 1971. Tentative Lower Cretaceous calcareous nannoplankton zonation. Eclog. Geol. Helv., 64, 459-488.

Thierstein, H. R. 1973. Lower Cretaceous calcareous nannoplankton biostratigraphy. Abh. Geol. B.-A., 29, 1-52.

Thierstein, H. R. 1974. Calcareous nannoplankton-Leg 26, Deep Sea Drilling Project. In Davies, T. A., Luyendyk, B. P., et al. Init. Repts. DSDP, Washington (U.S. Govt. Printing Office), 26, 619-667.

Thierstein, H. R. 1976. Mesozoic calcareous nannoplankton biostratigraphy of marine sediments. Mar. Micropaleontol., 1, 325-362.

Tyson, R. V. \& Funnell, B. M. 1987. European Cretaceous shorelines, stage by stage. Palaeogeog., Palaeoclimatol., Palaeoecol., 59, 69-91.

Verbeek, J. W. 1977. Calcareous nannoplankton biostratigraphy of middle and Upper Cretaceous deposits in Tunisia, southern Spain and France. Utrecht Micropaleontol. Bull., 16, 1-157.

Watkins, D. K. \& Bowdler, J. L. 1984. Cretaceous calcareous nannofossils from Deep Sea Drilling Project Leg 77, southeast Gulf of Mexico. In Buffler, R. T., Schlager, W., et al.Init. Repts. DSDP, Washington (U.S. Govt. Printing Office), 77, 649-674.

Wiegand, G. E. 1984. Jurassic nannofossils from the northwest African margin, Deep Sea Drilling Project Leg 79. In Hinz, K., Winterer, E. L.. et al., Init. Repts. DSDP, Washington (U.S. Govt. Printing Office), 79,57-670. 
Wise, S. W. 1983. Mesozoic and Cenozoic calcareous nannofossils recovered by Deep Sea Drilling Project Leg 71 in the Falkland Plateau Region, Southwest Atlantic Ocean. In Ludwig, W. J., Krasheninikov, V. A., et al. Init. Repts. DSDP, Washington (U.S. Govt. Printing Office), 71, 481550 .

Wise, S. W. \& Wind, F. H. 1977. Mesozoic and Cenozoic calcareous nannofossils recovered by DSDP Leg 36 drilling on the Falkland Plateau southwest Atlantic sector of the Southern Ocean. In Barker, P. F., Dalziel, I. W. D. et al., Init. Repts. DSDP, Washington (U.S. Govt. Printing Office), 36, 269-491.

Ziegler, P. A. 1982. Geological Atlas of Western and Central Europe. Shell. Internationale Petroleum Maatschappij B. V., 130pp.

\section{APPENDIX 1}

Stratigraphic details of samples collected at Munday's Hill, Leighton Buzzard, Bedfordshire, England, Grid Ref. SP939279. Bed numbers from Owen (1972).
Sample No.

$\begin{array}{ll}11 & 1, \text { base } \\ 12 & 1, \text { top } \\ 13 & 2(\mathrm{ii}) \\ 14 & 2(\mathrm{iii}-\mathrm{iv}) \\ 15 & 2(\mathrm{v}), \text { near } \\ \text { base } & \\ 16 & 2(\mathrm{v}) \\ 17 & 2(\mathrm{v}) \\ 18 & 2(\mathrm{v}) \\ 19 & 2(\mathrm{v}), \text { near }\end{array}$

top

20

21

22

23

24

base

25

26

27

28

base

29

top

30

31

$32-46$

\section{Bed}

3 (ii)?

3 (iii)

3 (iv)

3 (v)

4 (i), near

4(i), near top

4 (ii)

4 (iii)

4 (v), near

4 (v), near

4 (ix)

5

6
Samples $13-41$ are approximately spaced every $30 \mathrm{~cm}$.

Samples $41-46$ every $120 \mathrm{~cm}$.

\section{APPENDIX 2}

Nannofossil species considered in this study.
Corollithion achylosum (Stover 1966) Thierstein 1971

Rhagodiscus achlyostaurion (Hill 1976) Doeven 1983

Braarudosphaera africana Stradner 1961

Axopodorhabdus albianus (Black 1967) Wind and Wise in Wise and Wind 1977

Hayesites albiensis Manivit 1971

Bukrylithus ambiguus Black 1971

Calculites anfractus (Jakubowski 1986) Varol and Jakubowski 1989

Crucicribrum anglicum Black 1973

Cretarhabdus angustiforatus (Black 1971) Bukry 1973

Rhagodiscus angustus (Stradner 1963) Reinhardt 1971

Staurolithites angustus (Stover 1966) n. comb.

Rhagodiscus asper (Stradner 1963) Reinhardt 1967

Watznaueria barnesae (Black in Black and Barnes 1959) PerchNielsen 1968

Braarudosphaera bigelowii (Gran and Braarud 1935) Deflandre 1947

Watznaueria biporta Bukry 1969

Braloweria boletiformis (Black 1972) n. comb.

Ceratolithina bicornuta Perch-Nielsen 1988

Broinsonia Bukry 1969

Watznaueria britannica (Stradner 1963) Reinhardt 1964

Reinhardtites brooksii (Bukry 1969) Reinhardt 1971

Calculites Prins and Sissingh in Sissingh 1977

Lithraphidites carniolensis Deflandre 1963

Microstaurus chiastius (Worsley 1971) Grün in Grün and Allemann 1975

Chiastozygus sp. Gartner 1968

Haqius circumradiatus (Stover 1966) Roth 1978

Glaukolithus compactus (Bukry 1969) Perch-Nielsen 1984

Cretarhabdus conicus Bramlette and Martini 1964

Tetrapodorhabdus coptensis Black 1971

Grantarhabdus coronadventis (Reinhardt 1966) Grün in Grün and Allemann 1975

Cretarhabdus crenulatus Bramlette and Martini 1964

Crepidolithus sp. Noël 1965

Prediscosphaera cretacea (Arkhangelsky 1912) Gartner 1968

Staurolithites crux (Deflandre in Deflandre and Fert 1954) Caratini 1963

Ceratolithina cruxii Perch-Nielsen 1988

Truncatoscaphus sp. cf. T. delftensis (Stradner and Adamiker 1966) Rood, Hay and Barnard 1971

Axopodorhabdus dietzmannii (Reinhardt 1965) Wind and Wise 1983

Biscutum dissimilis Wind and Wise in Wise and Wind 1977

Cribrosphaera ehrenbergii Arkhangelsky 1912

Biscutum ellipticum (Górka 1957) Grün in Grün and Allemann 1975

Nannoconus elongatus Brönnimann 1955

Zeugrhabdotus embergeri (Noël 1959) Perch-Nielsen 1984

Zeugrhabdotus erectus (Deflandre in Deflandre and Fert 1954)

Reinhardt 1965

Sollasites falklandensis Wind and Wise in Wise and Wind 1977

Percivalia fenestrata (Worsley 1971) Wise 1983

Scapholithus fossilis Deflandre in Deflandre and Fert 1954

Tranolithus gabalus Stover 1966

Gartnerago Bukry 1969

Corollithion geometricum (Gorka 1957) Manivit 1971

Lapideacassis glans Black 1971

Hemipodorhabdus gorkae (Reinhardt 1969) Grün in Grün and 
Albian calcareous nannofossils

\author{
Allemann 1975 \\ Gaarderella granulifera Black 1973 \\ Ceratolithina hamata Martini 1967 \\ Crucibiscutum hayi (Black 1971) Jakubowski 1986 \\ Owenia hilli $\mathrm{n}$. sp.
}

Sollasites horticus (Stradner et al. in Stradner and Adamiker 1966)

Cepek and Hay 1969

Discorhabdus ignotus (Górka 1957) Perch-Nielsen 1968

Cretarhabdus inaequalis Crux 1987

Rhagodiscus infinitus (Worsley 1971) Applegate et al. in Covington and Wise 1987

Rucinolithus irregularis Thierstein in Roth and Thierstein 1972

Kamptnerius Deflandre 1959

Cylindralithus laffittei (Noël 1957) Black 1973

Lithastrinus sp. Stradner 1962

Chiastozygus litterarius (Górka 1957) Manivit 1971

Sollasites lowei (Bukry 1969) Roth 1970

Cretarhabdus madingleyensis (Black 1971) Crux 1989

Cyclagelosphaera margerelii Noël 1965

Lapideacassis mariae Black 1971

Staurolithites matalosus (Stover 1966) Cepek and Hay 1969

Grantarhabdus meddii Black 1971

Nannoconus minutus Bronnimann 1955

Eiffellithus monechiae n. sp.

Zeugrhabdotus noeliae Rood et al. 1971

Flabellites oblongus (Bukry 1969) Crux in Crux et al. 1982

Lithastrinus orbiculatus (Forchheimer 1972) Crux in Crux et al. 1982

Tranolithus orionatus (Reinhardt 1966) Perch-Nielsen 1968

Watznaueria ovata Bukry 1969

Repagulum parvidentatum (Deflandre in Deflandre and Fert 1954)

Forchheimer 1972

Manivitella pemmatoidea (Deflandre in Manivit 1965) Thierstein 1971

Lithastrinus planus (Stover 1966) Crux in Crux et al. 1982

Lithastrinus sp. cf. L. planus

Gartnerago praeobliquum Jakubowski 1986

Seribiscutum primitivum (Thierstein 1974) Filewicz et al. in Wise and Wind 1977

Corollithion protosignum Worsley 1971

Octocyclus reinhardtii (Bukry 1969) Wind and Wise in Wise and Wind 1977

Corollithion rhombicum (Stradner and Adamiker 1966) Bukry 1969

Cyclagelosphaera rotaclypeata Bukry 1969

Crucibiscutum saleborosum (Black 1971) Jakubowski 1986

Tegulalithus septentrionalis (Stradner 1963) Crux 1986

Corollithion signum Stradner 1963

Zeugrhabdotus sisyphus (Gartner 1968) Crux 1989

Prediscosphaera spinosa (Bramlette and Martini 1964) Gartner 1968

Rhagodiscus splendens (Deflandre 1953) Verbeek 1977

Tegumentum striatum (Black 1971) Crux 1989

Cretarhabdus striatus (Stradner 1963) Black 1973

Viminites swinnertonii (Black 1971) Black 1975

Tegulalithus tessellatus (Stradner in Stradner et al. 1968) Crux 1986

Helicolithus trabeculatus (Górka 1957) Verbeek 1977

Nannoconus truittii Brönnimann 1955 